\title{
Synthesis of Some New Sulfanilamide Derivatives
}

\author{
Haiffaa Y. Hussain
}

Department of Chemistry/College of science/Mosul University

Received

$14 / 5 / 2006$
Accepted

2006/9/4

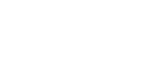

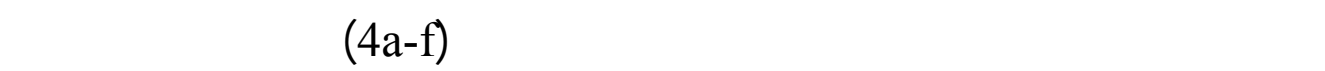

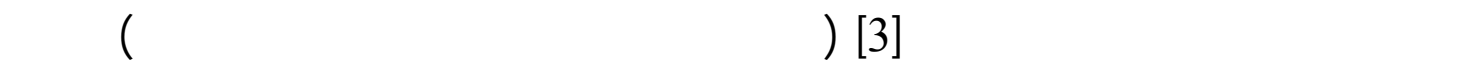

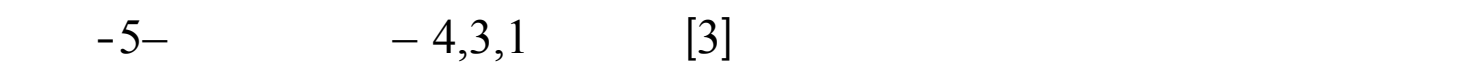
[5] الذي عند مفاعلته مع هاليدات الالكل والالديهايدات اعطى المركبات (7,6 ) و (9a-b) )

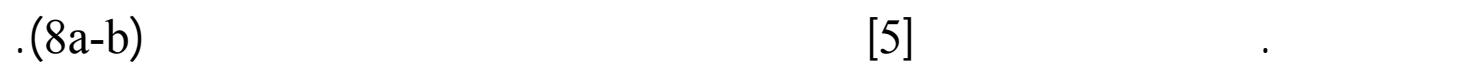
شخصت المركبلت المحضرة اعتمادا على الطرائق الفيزياوية والطفية.

\section{ABSTRACT}

The synthesis of amino acid hydrazide derivatives (4a-f) has been achieved by condensation of the corresponding amino acid hydrazide [3] (which synthesized from sulfanilamide as starting material) with aldehydes or ketones. Compound [3] is also used as a synthone to obtain 1,3,4-oxadiazole-5-thiole [5], which upon reaction with alkyl halide and aldehyde gave compounds $(6,7)$ and $(9 a-b)$ respectively. Compound [5] was also allowed to undergo Mannich reaction to give compounds (8a-b).

The structure of the synthesized compounds has been confirmed by physical and spectral methods .

\section{INTRODUCTION}

Some of substituted 1,3,4-Oxadiazoles are considered to be compounds possessing pharmaceutical effects, they applied as antibacterial $^{(1,2)}$ fungicidal $^{(3,4)}$, and anti microbial agents ${ }^{(5,6,7)}$. Some oxadiazol 2-thioles were used to inhibit the mono amine oxidase and succinate dehydrogenase activity ${ }^{(8)}$, nematocidal, insecticidal and herbicidal activity ${ }^{(9)}$.Finally methoxy phenyl oxadiazole derivatives were used as anti-5-hydroxy tryptamine receptor lengitudinal muscle myenteric plexus ${ }^{(10)}$.

The common synthetic approache for oxadiazoles involve cyclization of diacyl- hydrazines ${ }^{(11)}$. A variety of reaction conditions influence the cyclization path way .Typically reaction is promoted by 
heat and dehydrating agents including thionyl chloride ${ }^{(12)}$, and phosphorous pentoxide ${ }^{(13)}$.

Alternative synthetic methods comprise reaction of phosphorous oxychloride and thiosemicarbazide which on chemoselective heterocyclization with mercuric or lead oxide ${ }^{(14)}$.Keeping all this in view, it was thought worth while to synthesize some new oxadiazole derivatives in a goal that the presence of sulfanilamide moiety might confer enhancement of the biological activity.

\section{EXPERIMENTAL}

Melting points were determined on Electrothermal melting point apparatus 9300 and were uncorrected .IR. spectra were recorded on PyeUnicam SP2000 Infra red Spectrophotometer using (KBr) disk . Ultra violet spectroscopy were recoerded on Shimadzu (UV-160) UV-visible recording spectrophotometer. The physical and spectral data of the compounds [1-9] were listed in table (1).

\section{1- Preparation of N-(4-sulfamoyl phenyl)alanine (1) ${ }^{(15)}$ :}

Sulfanilamide $(0.01$ mole $)$ was dissolved in $(50 \mathrm{ml})$ of absolute ethanol containing ( 0.01 mole) of pyridine. 2 -Bromo propanoic acid $(0.01$ mole) was added slowly with stirring, then the reaction mixture was reflux for (24 hours). The solution was concentrated to a half and crushed ice was added. After ( 24 hours), the crude material was filtered off, washed with cold water and recrystallized from water, giving white crystals ; m.p $\left(147-149^{\circ} \mathrm{C}\right)$.

\section{2- Preparation of Ethyl-2-(N-sulfamoyl phenyl )alaninate (2) ${ }^{(16)}$ :}

Thionyl chloride $(0.015$ mole $)$ was added to $(0.01$ mole $)$ of compound (1) with continuous cooling and stirring, then the excess of thionyl chloride was evaporated and $(25 \mathrm{ml})$ of absolute ethanol was added, the mixture was refluxed for ( 3 hours). The mixture was evaporated to obtain solid product which recrystallized from ethanolwater, giving white crystals ; m.p $\left(108-109^{\circ} \mathrm{C}\right)$.

\section{3- Preparation of N-(4-sulfamoyl phenyl)alanine hydrazide (3) ${ }^{(17)}$ :}

A solution of compound (2) (0.01 mole) and hydrazine hydrate $(0.015$ mole $)$ in $(50 \mathrm{ml})$ of absolute ethanol was refluxed for (24 hours).The solution was concentrated to a half and crushed ice was added. After (4 hours), the solid product was filtered off, recystallized from water , giving white crystals ; m.p $\left(204-206^{\circ} \mathrm{C}\right)$. 
4- Preparation of $\mathrm{N}$-(4-sulfamoyl phenyl)alanine hydrazide aldimines and

ketimines (4a-f) ${ }^{(18)}$ :

A mixture of compound (3) (0.005 mole) and aldehyde or ketone $(0.01 \mathrm{~mole})$ in $(50 \mathrm{ml})$ of methanol was refluxed for (24 hours). The solvent was evaporated and the product was recrystallized from ethanolwater.

\section{5- Preparation of 2-[ $\alpha$-(4-sulfamoyl phenyl)amino]ethyl-1,3,4-} oxadiazoline-5thione (5) ${ }^{(19)}$ :

Carbon disulfide $(0.1$ mole, $6 \mathrm{ml})$ was added gradually to a solution containing compound (3) (0.005 mole) and potassium hydroxide $(0.005 \mathrm{~mole})$ in $(70 \mathrm{ml})$ ethanol . The mixture was refluxed for (48 hours) until the liberation of hydrogen sulfide was ceased (cheked by moist paper with lead acetate). The solvent was concentrated under reduced pressure and the residue was poured on crushed ice. The crude product was filtered off, washed with cold water and recrystallized from methanol, giving yellowish crystals .m.p $\left(123-125^{\circ} \mathrm{C}\right)$.

6- Preparation of 2-[ $\alpha$-(4-sulfamoyl phenyl)amino]ethyl-5-alkyl mercapto-

\section{1,3,4-oxadiazole (6-7) ${ }^{(16)}$ :}

A mixture of compound (5) (0.001 mole), sodium acetate $(0.0024$ mole) and alkyl halid (0.001 mole) in $(20 \mathrm{ml})$ of methanol was refluxed for (16 hours). The solvent was evaporated and the product was recrystallized from ethanol-water.

\section{7-Preparation of 2-[a-(4-sulfamoyl phenyl) amino] ethyl-4- substituted amino \\ methylene-1,3,4-oxadiazoline-5-thione (8a-b) ${ }^{(20)}$ :}

A solution of para formaldehyde $(0.0033$ mole $)$ and secondary amine $(0.005$ mole $)$ in $(10 \mathrm{ml})$ methanol were refluxed for half an hour then a solution of $(0.0013$ mole $)$ of compound $(5)$ in $(15 \mathrm{ml})$ of methanol was added and the reflux was continued for ( 24 hours). The hot filtration and evaporation of the solvent afforded the product which recrystallized from ethanol-water.

8- Preparation of 2-[ $\alpha$-(4-sulfamoyl phenyl)amino]ethyl-4- $\alpha$-hydroxy alkyl-

\section{1,3,4-oxadiazoline-5-thione $(9 a-b){ }^{(21)}$ :}

A mixture of (0.002 mole) of compound (5) and (0.002 mole) of aldehyde in $(25 \mathrm{ml})$ of methanol was refluxed with stirring for (10 hours). The solvent was evaporated and the crude product was recrystallized from ethanol-water. 


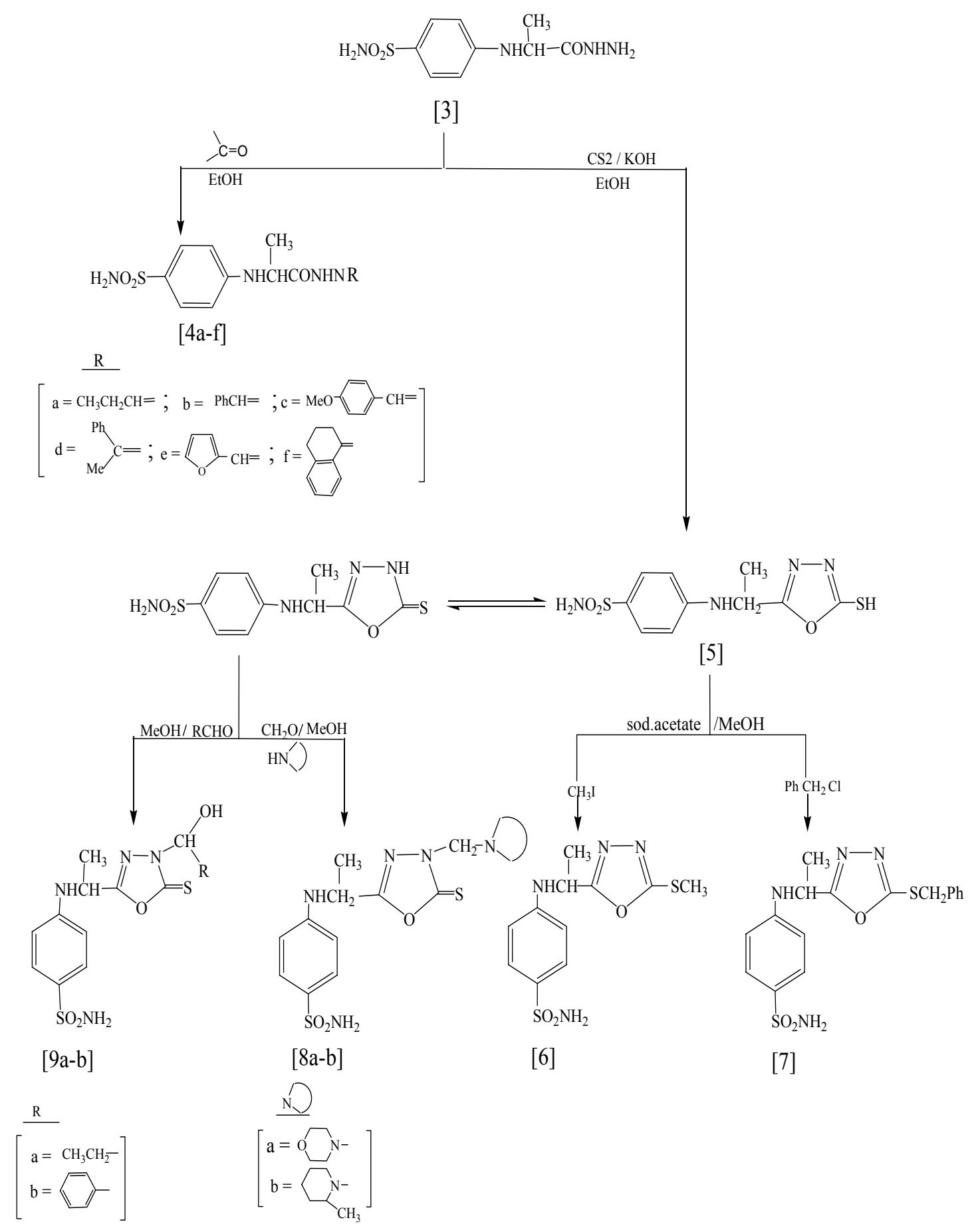

Scheme (1)

\section{RESULTS AND DISCUSSION}

$\mathrm{N}$-(4-sulfamoyl phenyl)alanine [1] was synthesized from the reaction of sulfanilamide with 2-bromopropanoic acid [scheme (2)]. Compound [1] was then esterified to give the corresponding ester [2]. The hydrazide derivatives of the ester [3] was prepared according to the well known procedure ${ }^{(17)}$.The structure of compounds [1-3] were elucidated through the physical properties and the spectral data (table 1). The IR 
spectra of these compounds show main absorption bands at $(3355,3313-$ 3355 and $1638-1727 \mathrm{~cm}^{-1}$ ) assigned to $\mathrm{O}-\mathrm{H}, \mathrm{N}-\mathrm{H}$ and $\mathrm{C}=\mathrm{O}$ respectively, and they show two vibration modes, asym. at $\left(1314-1339 \mathrm{~cm}^{-1}\right)$ and sym. at $\left(1164-1218 \mathrm{~cm}^{-1}\right)$ due to $\mathrm{SO}_{2}$ group ${ }^{(21)}$. The ultraviolet absorptions of these compounds show a bathochromic shift at $(258-269 \mathrm{~nm})$ which is attributed to the $n \rightarrow \pi^{\star}$ transitions.<smiles></smiles><smiles></smiles>

[1]<smiles>CC(C=O)Nc1ccc(S(N)(=O)=O)cc1</smiles>

[2]<smiles></smiles>

[3]

\section{Scheme (2)}

Hydrazone compounds [4a-f] were synthesized by the condensation of hydrazide [3] with aldehydes or ketones. The mechanism of hydrazone formation could be occurred through addition-elemination reaction ${ }^{(22)}$ as illustrated as follow:

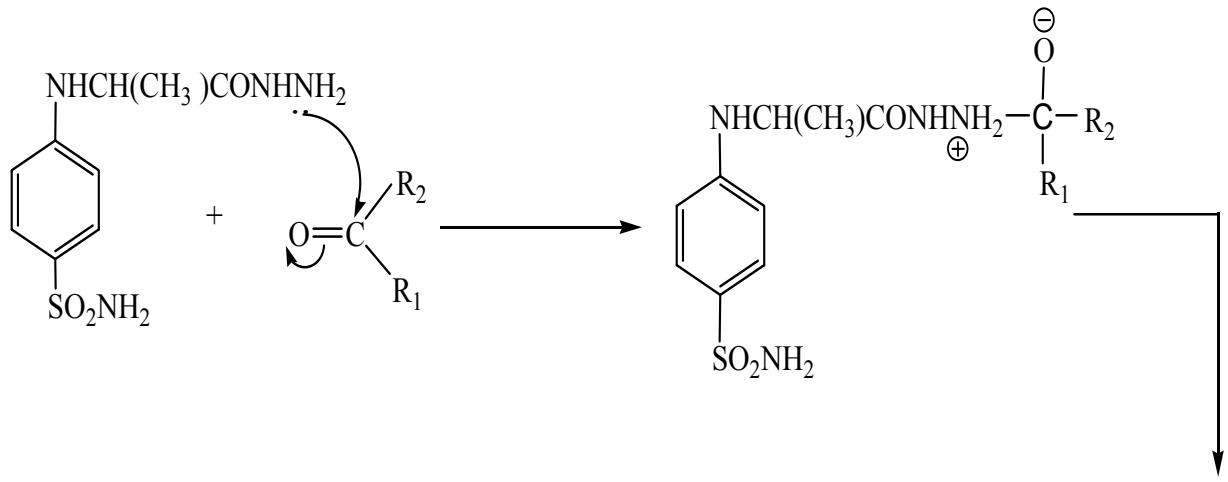

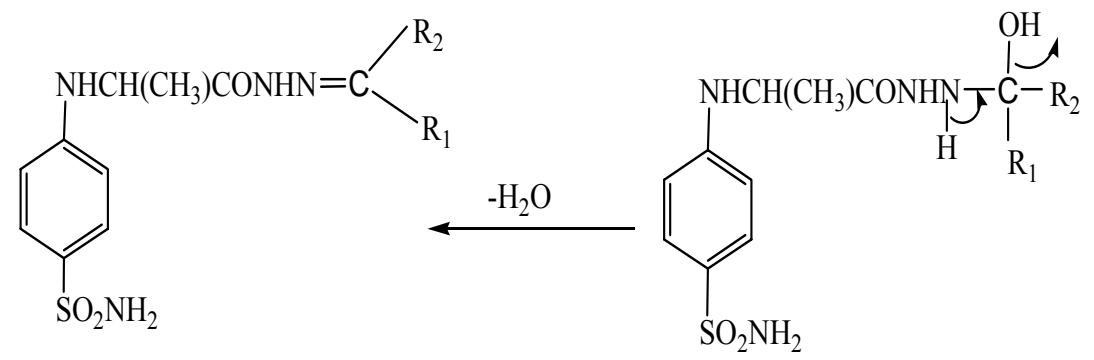

Scheme (3) 
The IR. spectra of compounds [4a-f] (Table 1) showed absorption bands at $\left(3342-3376 \mathrm{~cm}^{-1}\right)$ belong to $\mathrm{N}-\mathrm{H},\left(1672-1688 \mathrm{~cm}^{-1}\right)$ assigned to $\mathrm{C}=\mathrm{O}$ group and $\left(1600-1622 \mathrm{~cm}^{-1}\right)$ corresponds to the $\mathrm{C}=\mathrm{N}$ stretching absorption. The UV absorption spectra for these compounds showed absorption bands at (265-298 nm) due to the oxychromic effect by N-H group.

Oxadiazole [5] was obtaind by the reaction of hydrazide [3] and carbon disulfide in alkaline medium . The mechanism of the reaction is accomplished by nucleophilic attack of nitrogen hydrazide at the carbon atom of carbon disulfide to form the xanthat salts (a) which undergoes intra nucleophilic attack of the oxygen of the carbonyl group on the carbon of $\mathrm{C}=\mathrm{S}$ group followed by elimination of hydrogen sulfide to afford oxadiazole-2-thiole ${ }^{(23)}$.

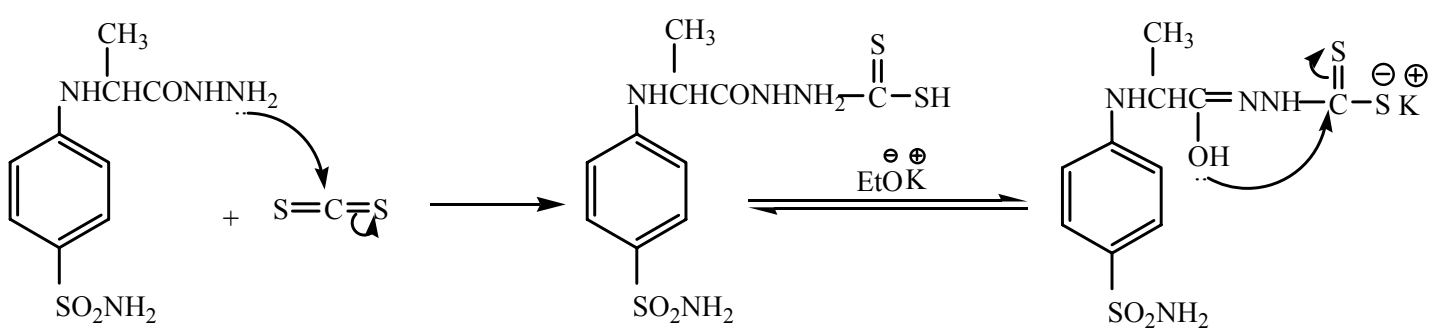

(a)<smiles>CC(C)c1nnc([Hg])o1</smiles><smiles>CC(Nc1ccc(S(N)(=O)=O)cc1)c1nnc(S)o1</smiles><smiles>CC(c1ccc(S(N)(=O)=O)cc1)c1n[nH]c(=S)o1</smiles>

[5]

Scheme (4) 
The IR.spectrum of compound [5] showed absorption bands at $\left(1145 \mathrm{~cm}^{-1}\right)$ corresponds to the thione stretching vibration, and the others gave the following vibrational absorption bands are shown at $(3394,1598$ and $1518 \mathrm{~cm}^{-1}$ ) which are assigned to $\mathrm{N}-\mathrm{H}, \mathrm{C}=\mathrm{N}$ and $\mathrm{C}=\mathrm{C}$ group respectively.

Compounds [6,7] were prepared by treating the corresponding oxadizaoline thione [5] with methyl iodide in presence of sodium acetate. The structure of compounds [6-7] were confirmed by their IR spectral data which showed the major absorption bands at $\left(1597-1598 \mathrm{~cm}^{-1}\right)$ and at $\left(876-865 \mathrm{~cm}^{-1}\right)$ which are related to $\mathrm{C}=\mathrm{N}$ and $\mathrm{C}-\mathrm{S}-\mathrm{C}$ groups respectively , while the reaction of oxadiazoline thione [5] with aldehyde afforded compounds [9a-b] .The IR spectra of compounds [9a-b] showed the following main absorption bands: $\left(3350-3385 \mathrm{~cm}^{-1}\right)$ for N-H band, (1597$\left.1598 \mathrm{~cm}^{-1}\right)$ for $\mathrm{C}=\mathrm{N}$ band and at $\left(1154-1162 \mathrm{~cm}^{-1}\right)$ for $\mathrm{C}=\mathrm{S}$ band. The final compounds $[8 \mathrm{a}-\mathrm{b}]$ were prepared according to the reported procedure ${ }^{(24)}$, their structure were confirmed by IR. spectroscopy which showed the following main bands $\left(3400-3420 \mathrm{~cm}^{-1}\right)$ for N-H band , $\left(1597-1598 \mathrm{~cm}^{-1}\right)$ for $\mathrm{C}=\mathrm{N}$ and $\left(1158-1163 \mathrm{~cm}^{-1}\right)$ for $\mathrm{C}=\mathrm{S}$ band. In UV spectra these compounds showed red shift at ( $264-271 \mathrm{~nm})$ due to the $\mathrm{n} \rightarrow \pi^{\star}$ transitions . 

Table (1) : The physical and spectral data of the compounds [1-9]

\begin{tabular}{|c|c|c|c|c|c|c|c|c|c|c|}
\hline \multirow{2}{*}{$\begin{array}{c}\text { Compd. } \\
\text { No. }\end{array}$} & \multirow{2}{*}{$\begin{array}{l}\text { M.P } \\
\left({ }^{\circ} \mathrm{C}\right)\end{array}$} & \multirow{2}{*}{$\begin{array}{l}\text { Yield } \\
\text { (\%) }\end{array}$} & \multirow{2}{*}{$\begin{array}{c}U . V E t O H \\
\lambda_{\max }(n m)\end{array}$} & \multirow[b]{2}{*}{$\boldsymbol{C}=\boldsymbol{O}$} & \multicolumn{6}{|c|}{ I.R. $(\mathrm{KBr}) v \mathrm{~cm}^{-1}$} \\
\hline & & & & & $C=N$ & $C=S$ & $\begin{array}{r}S O \\
\text { asym }\end{array}$ & 2 sym & $\mathrm{N}-\mathrm{H}$ & $O-H$ \\
\hline 1 & $147-149$ & 87 & 258 & 1727 & - & - & 1314 & 1218 & 3300 & 3355 \\
\hline 2 & 108-109 & 76 & 268 & 1726 & - & - & 1345 & 1164 & 3313 & - \\
\hline 3 & 204-206 & 80 & 269 & 1638 & - & - & 1339 & 1170 & 3353 & - \\
\hline $4 a$ & $101-103$ & 72 & 270 & 1672 & 1622 & - & 1340 & 1162 & 3342 & - \\
\hline $4 b$ & 290-292 & 80 & 265 & 1674 & 1602 & - & 1322 & 1149 & 3388 & - \\
\hline $4 c$ & 201-203 & 78 & 290 & 1672 & 1603 & - & 1346 & 1161 & 3394 & - \\
\hline $4 d$ & $188-190$ & 75 & 267 & 1660 & 1601 & - & 1331 & 1156 & 3351 & - \\
\hline $4 e$ & $240-242$ & 70 & 298 & 1674 & 1602 & - & 1322 & 1149 & 3386 & - \\
\hline $4 f$ & $244-246$ & 82 & 270 & 1688 & 1600 & - & 1313 & 1152 & 3376 & - \\
\hline 5 & $123-125$ & 81 & 268 & - & 1598 & 1145 & 1340 & 1145 & 3394 & - \\
\hline 6 & 109-111 & 75 & 271 & - & 1597 & - & 1338 & 1163 & 3340 & - \\
\hline 7 & $119-121$ & 85 & 270 & - & 1598 & - & 1330 & 1164 & 3330 & - \\
\hline $8 \mathbf{a}$ & $144-146$ & 89 & 264 & - & 1598 & 1163 & 1356 & 1159 & 3420 & - \\
\hline $8 b$ & $155-157$ & 85 & 270 & - & 1597 & 1158 & 1336 & 1158 & 3400 & - \\
\hline $9 a$ & $166-168$ & 80 & 269 & - & 1598 & 1162 & 1340 & 1162 & 3350 & 3540 \\
\hline $9 b$ & $153-156$ & 90 & 268 & - & 1597 & 1154 & 1350 & 1154 & 3385 & 3470 \\
\hline
\end{tabular}





\section{REFERENCES}

1. Pang,H.; Zhany,J.R.; Shai,X., and Wang, J.H., J.Chin.Pharm.Sci., 7(2), 110 (1998).

2. Jassim,A.H.; AL-Hasani,R.A.N. and AL-Mumin,T.M., National J.Chem., 2, 215 (2001).

3. Rai,K.M.; Manoj,K.C.; Shetty,H.; Rajasekhara,K.P. and Nirajana,N., Indian J.Heterocyclic Chem.,8(4), 335(1999).

4. Herbert,B.; Markus,G.; Thomas,G.; Bernd,M.; Herbert,S.; Wassilion,G.; and Andeeas,G., Ger.Offen.DE19 , 745,650 (CIC O7D 4/3/12) 22, Apr., Appl.19, 745,650.160 ct, 1997, 96pp. (Ger),(1999).

5. Ibrahim,L.M.; Ahmed H.M.; Omaima,A.M. and Kader,O; Montash Chem.,120,571(1989).

6. Vashi,R.S.; Mchta,D.S., and Shah,V.H., Indian J. Chem., 35B,111(1996).

7. Demirbas,N.; Demirbas,A.; Karaoglu,S.A. and Celike,E., Arkivoc (i),75 (2005).

8. Soni,N.; Barthwal,J.P.; Saxena,A.K.; Bahargava,K.P., and Parmar,S.S., J. Heterocyclic Chem.,19,29.Synth. Commun, 30, 437 (1982).

9. Shaban,M.A.E. ; Nasr,A.Z. and EL-Badry,S.M., J.of Islamic academy of Scie- nces, 4:3,184(1991).

10. Takeshi,S.; Kiuoshi,I.; Naoki,I.; Yukinori,N.; Keiji,M.; Hideaki,N.; Mitsuaki, O., and Toshiyasu,M., Chem. Pharm.Bull, 47(1),120 (1999).

11. Bentiss,F. and Lagrenee,M., J.Heterocyclic Chem.36, 1029 (1999).

12. AL.Talib,M. ; Tastoush,H. and Odeh,N., Synth.Commun,20, 1811 (1990).

13. Daoud K.M. and Eisa M.A., National J.of Chemistry, 7,438 (2002).

14. Ahmed,B.A. and Ayoub,M.T.; Mohamed, S.J.; Raf.J.Sci., 12(3),33 (2001).

15. Pachhamia,V.L. and Parikh,A.R., J. Indian Chem. Soc. , 66(4) ,250 (1989).

16. Mahmoud,M.J.; Mustafa,I.F. and Atto,A.T. , Mutah J. for Research and Studies, 11 (5),155 (1996).

17. Daoud K.M. and Al-Naimi,K.H., National J.Chem.,8,603 (2002).

18. Mansour,A .K. ;Eid,M.M. and Khalil,N.S.A.M., Molecules, 8,744-755 (2003).

19. Shandala ,M.Y.;Ayoub,M.T. and Noori,M.S., Raf. J. Sci. , 9(2), 34(1998).

20. El-Masry,A .H.;Fahmy,H.H. and Ali Abdel wahed,S.H., Molecules , 5,1429- 1438 (2000).

21. Parikh, V.M., "Absorption Spectroscopy of Organic Molecules”, Addition Wesley Publishing Company, London, 325(1974).

22. Hammett, I.P., "Physical Organic Chemistry", McGraw-Hill Book Co.Inc. New ork, 163, (1940).

23. Ajllo,E.; Migliara,O. and Sprio,V., J. Heterocyclic Chem., 9, 1169,(1972).

24. Al-Ajely,M.S.; Basher,H.A.; Hussin,H.Y., , J.Edu. Sci.,15(1), 18(2002). 